to a level worthy of the traditions of a famous medical school.

A generous donation from a personal friend, the late Mr. Lawrence Pullar of Bridge of Earn, formed the nucleus for the provision of a new department, and largely owing to Ashworth's energy and personality the necessary funds were raised. He visited many laboratories at home and in America to gather ideas for use in planning a new department. In 1927 he succeeded Cossar Ewart in the chair of natural history, and in 1929 one of his objects was achieved when H.R.H. Prince George opened the new laboratories at West Mains Road. This building was the result of careful thought, and the successful way in which it fulfils its purposes is a tribute to Ashworth's marked skill in organisation. The second object was always present in his thoughts, and not a year passed that did not see an improvement in the medical courses.

Ashworth's grasp of detail, the care with which he studied any matter requiring his attention, his sound judgment and courteous consideration for the opinions of others, enabled him to fill many executive positions in the University and in learned societies with outstanding efficiency. As a teacher he was most conscientious, painstaking and successful, and his devotion to his work was a source of inspiration to all connected with him. While his own research was in the domain of invertebrate zoology, his catholic reading and retentive memory made him at home also in vertebrate work, and there are few zoologists with such an all-round knowledge. The department is enriched by specimens he brought back from two visits to America, one to South Africa and one to Australia. To his students, colleagues and friends he gave ungrudgingly of his best, and his sudden death on the morning of Tuesday, February 4, came to them all as a deep personal loss. NATURE itself loses a constant friend, whose contributions and advice over a long period of years have been of the greatest value.

In his earlier life, Ashworth played the piano and always retained a love of music. He was a sincere and kindly man whose charm of manner and engaging personality won him many friends. He is survived by his widow, who throughout his life in Edinburgh shared his labours and achievements.

\section{Mr. R. Southern}

THe sudden and unexpected death, on December 13 in Dublin, of Mr. R. Southern, has taken away one of the keenest and most thorough students of fresh-water biology in its relation to fisheries in the British Isles.

Rowland Southern was born in 1882 at Adlington in Lancashire, and, after an early training in chemistry, obtained a post, in 1902, in the office of the City Analyst in Dublin. His natural bent was, however, towards biology, and in 1906 he received an appointment in the Natural History Section of the Irish National Museum, resigning this post in 1911 for one in the Fisheries Branch of the Department of Agriculture and Technical Instruction.
During his time in the Museum, Southern took up the study of annelids and other worms, and, in a short time, made himself a recognised authority. $\mathrm{He}$ continued this study while engaged in the general fishery work of the Department, publishing, at frequent intervals, papers on the various groups, mainly based on his own observations and collections.

During the Great War, Southern's application for active service having been rejected on the grounds of short sight, he was for a time in charge of the Department's efforts to promote increased utilisation of fresh-water fish as a source of food. This gave a now direction to his interests. In 1920, a Limnological Laboratory, the first adequately equipped fresh-water station in the British Isles, was established on the River Shannon close to Lough Derg, under the control of the Department, with the aid of funds supplied by the Development Commissioners, and he was put in charge. From that time, the study of fresh water biology, mainly in its ecological aspect, was his chief preoccupation. It was in the course of his work on Lough Derg that his attention was directed to the difference in size of trout in acid and limestone waters, and the search for an adequate explanation formed the background of all his subsequent investigations, for the cause usually alleged, that of more abundant food in the alkaline waters, did not, as he pointed out, agree with the facts.

At the closure of the Limnological Laboratory in 1923, Southern's headquarters were transferred to Dublin and, with the problem of growth-rate in his mind, he planned an intensive survey of the productivity in fish food of the River Liffey and its tributaries by means of periodic quantitative collections during several years, both from the upper peaty waters and the lower limestone reaches. $\mathrm{He}$ also instituted the regular collection of salmon scales from the River Shannon, in order to elucidate the age and growth-rate of the fish in that river in connexion with the changes brought about by the new hydro-electric scheme. At the time of his death he was working on the collection of salmon scales, on which he had already published a first report, and was tabulating the results of the examination of an immense amount of material from the River Liffey, mainly insect larvæ, collected and named by himself and his willing helpers.

Southern's biological work, latterly, was done, for the most part, in his spare time, as his official hours were largely occupied by his manifold duties as an inspector dealing with the inland fisheries of the Irish Free State. He was an enthusiastic and expert angler and his knowledge, from practical experience, of the angling waters of Ireland, was unrivalled, and was freely put at the disposal of all inquirers at his official headquarters.

Southern was a frequent attendant at the meetings of the International Council for the Exploration of the Sea, as an expert on behalf of the Irish Free State, and was an active member of the Salmon and Trout Committee of that body. His death, in the midst of his work, leaves many friends in scientific and angling circles in Ireland and elsewhere to regret his loss.

G. P. F. 